\title{
Damaging Agents and Tree's Health Condition in an Urban Forest
}

\section{Luz de Lourdes Saavedra-Romero', Tomás Martínez-Trinidad ${ }^{2}$, Dionicio Alvarado-Rosales ${ }^{*}$, Patricia Hernández-de la Rosa ${ }^{2}$, Jaime Villa-Castillo ${ }^{3}$}

\author{
${ }^{1}$ Postgrado en Fitosanidad-Fitopatología, Colegio de Postgraduados, Campus Montecillo, Texcoco, Estado de México \\ ${ }^{2}$ Postgrado en Ciencias Forestales, Colegio de Postgraduados, Campus Montecillo, Texcoco, Estado de México \\ ${ }^{3}$ Consultor Independiente, Colegio de Postgraduados, Campus Montecillo, Texcoco, Estado de México \\ Email: *dionicio@colpos.mx
}

How to cite this paper: de Lourdes Saavedra-Romero, L., Martínez-Trinidad, T., Alvarado-Rosales, D., Hernández-de la Rosa, P., \& Villa-Castillo, J. (2021). Damaging Agents and Tree's Health Condition in an Urban Forest. Open Journal of Forestry, 11, 238-253.

https://doi.org/10.4236/ojf.2021.113016

Received: May 24, 2021

Accepted: July 3, 2021

Published: July 6, 2021

Copyright (c) 2021 by author(s) and Scientific Research Publishing Inc. This work is licensed under the Creative Commons Attribution International License (CC BY 4.0).

http://creativecommons.org/licenses/by/4.0/

\begin{abstract}
Urban trees are subjected to different damaging agents throughout their lifetime. The aims of this study were to identify tree damaging agents, and to obtain a Damage Severity Index (DSI) in order to categorize tree health condition at San Juan de Aragon Park. Each tree was identified at species level in 28 randomly established plots in ten sections of the study area. Up to two types of damage were recorded per tree, based on the FIA (Forest Inventory an Analysis Program) protocol, and a DSI was obtained for each damaged tree considering location of damage, nature of the damaging agent and severity. A total of 753 trees were assessed and 12 species and 27 damaging agents were identified. Cankers, galls, the pepper tree psyllid and the red gum lerp psyllid were the most frequent damaging agents. Australian pine, red gum, Mediterranean cypress, Mexican white cedar, and California pepper were the most affected species. The DSI ranged from 3 to 17 and the average was 7.9. Sections $\mathrm{J}$ and $\mathrm{H}$ and the species California pepper, Australian pine, and Mexican white cedar presented the highest DSI. The tree population had a moderate health condition, while the aforementioned sections and tree species showed the poorest.
\end{abstract}

\section{Keywords}

Damaging Agents, Urban Trees, Bleeding, Cankers, Galls, Health Categories, Damage Severity Index

\section{Introduction}

Trees have adapted to different environments and are the most important component of the urban environment due to their size, beauty, and close connection 
with people (Konijnendijk et al., 2005; Samson, 2017). However, tree health is negatively affected under urban conditions (Stone et al. 2003a) causing a reduction in their vitality and life expectancy (Nowak et al., 2004; Roman \& Scatena, 2011). Tree vitality (ability to grow, to reproduce, and to adapt to the surrounding), is reduced due to the limited and modified space in which trees are established (Pretzsch et al., 2015). The lack of vital resources for growth, such as water, organic matter, and nutrients in soils (Klieber et al., 2019) causes chronic stress which becomes worse over time. Besides, exposure to different damaging agents such as pathogens, insects, air pollution, vandalism and lack of management also undermine tree vitality. Along with these adversities, the species planted are generally not the most appropriate for the site. Selecting the right species for an urban area requires careful examination (i.e., potential constraints, tree ecophysiology, aesthetic and functional attributes, otherwise, the trees will be more susceptible to diseases and pests, and thus leading to extra-maintenance costs (removal and replacement, pruning, fertilization, etc.) (McPherson, 1993; Roman \& Scatena, 2011; Johnston \& Hirons, 2014; Bravo-Bello et al., 2020).

The identification and analysis of damaging agents can be expressed based on the incidence of biotic and abiotic factors (Ferretti, 1997). Any factor that negatively affects vitality and environmental and economic tree value is known as a damaging agent (Wulff, 2011). These, may act individually or synergistically, causing direct tissue loses, and the rot of cortex tissues in the stem, branches, and roots (Stone et al., 2003a). Regarding that, there are many examples about damaging agents causing urban tree stress and death (Alvarado-Rosales et al., 2007). Some of these include the emerald ash borer (Agrilus plannipenis Fairmaire), responsible for the death of 20 million ash trees in the United States alone (USDA, 2009). In Mexico, a case that attracted public attention was the effect of true mistletoe Cladocolea loniceroides Van Tieghem in Xochimilco Mayoralty, where approximately 2500 bonpland willows (Salix bonplandiana Kunth) died, and over 50 thousand had to be pruned to reduce infection levels (Alvarado-Rosales \& Saavedra-Romero, 2005).

For several years, previous research has mentioned the variables that can be used to evaluate and characterize the current health condition of natural and urban forests (Ferretti, 1997); however, these variables must be scientifically valid and economically feasible to collect (Stone et al., 2003b); some of the most studied variables are foliar discoloring, defoliation percentage, crown density, leaf and needle size, and damaging agents (one or more types of damage) (Conkling et al., 2005; Coulston et al., 2005). Although identifying tree damaging agents could be a simple task, expressing the damage in numerical terms is a complicated assignment because of the lack of linkages and thresholds, and the difficulty in interpreting damage (Conkling et al., 2005). Not to mention the DSI or other indexes, which integrate information from multiple variables in a single value, for example, the RUSI index for urban landscapes (Scharenbroch et al., 2017). Another, is the Canopy Damage Index (CDI) generated for Red gum 
plantations, for example, it was developed for plantation managers and forestry experts, who often need to quantify the degree of tree damage, whilst generating reliable data for an inventory of their resource condition, calculating losses, and implementing immediate management activities in the most heavily impacted sites (Stone et al., 2003a).

Regarding natural forests, the ICP Forest (International Cooperative Program on Assessment and Monitoring of Air Pollution Effects on Forest) is currently applying a protocol to determine damage to forest species, implementing three simple steps: (a) Description of the symptom (devoured, broken, tanned); (b) Determination of the causes (fungi, bacteria, insect, abiotic agent) and (c) Quantification of the symptom (extension of damage) focusing exclusively on the damage that could affect the tree as a complete entity (Lorenz, 2013; Michel et al., 2014). However, we still need additional studies focused on trees under urban environments.

Tree health assessment must be seen as a comprehensive process based on a visual and complete inspection of its organs (Alexander \& Palmer, 1999; Stone et al., 2003b). Damaging agents that affect the root and stem have a greater potential to affect the overall physiology of the tree, hence their presence is considered more dangerous (Conkling et al., 2005). Under other conditions, damage caused to active growth organs (small branches and foliage) may be temporary, since the leaves, sprouts, and reproductive structures can be replaced in the short or medium term (Conkling et al., 2005, Winn et al., 2011). Finally, the aims of this study were to identify tree damaging agents, and to obtain a Damage Severity Index (DSI), in order to categorize tree health condition of the San Juan de Aragon Park.

\section{Material and Methods}

\subsection{Study Area}

This study was carried out in the San Juan de Aragon Park, located northeastern Mexico City $\left(19^{\circ} 27^{\prime} 32^{\prime \prime N} ; 99^{\circ} 04^{\prime} 17^{\prime \prime} \mathrm{W}\right)$. This urban park is the second most important in the city with 114 ha of green area and about 3.5 million visitors annually. Out 14 sections that conform to the park, ten were chosen (B, C, E, F, G, $\mathrm{H}, \mathrm{J}, \mathrm{K}, \mathrm{L}$, and $\mathrm{M}$ ) (Figure 1) which in the past were classified according to their use and service (e.g. cultural and recreational activities, low impact sports, facilities, etc.) (SMA, 2012). In this sense, 28 circular plots of 0.1 hectare were established ( 2 to 6 plots per section), using a sampling intensity of $2.5 \%$. All plots were georeferenced and all trees (alive and dead) within their limits were numbered clockwise, starting from the geographic North; each tree was also identified taxonomically (Saavedra-Romero et al., 2019a).

\subsection{Damage Assessment}

The tree damage indicator protocol proposed by the Forest Inventory and Analysis Program and Conkling et al. (2005) was implemented. Beforehand, the field 


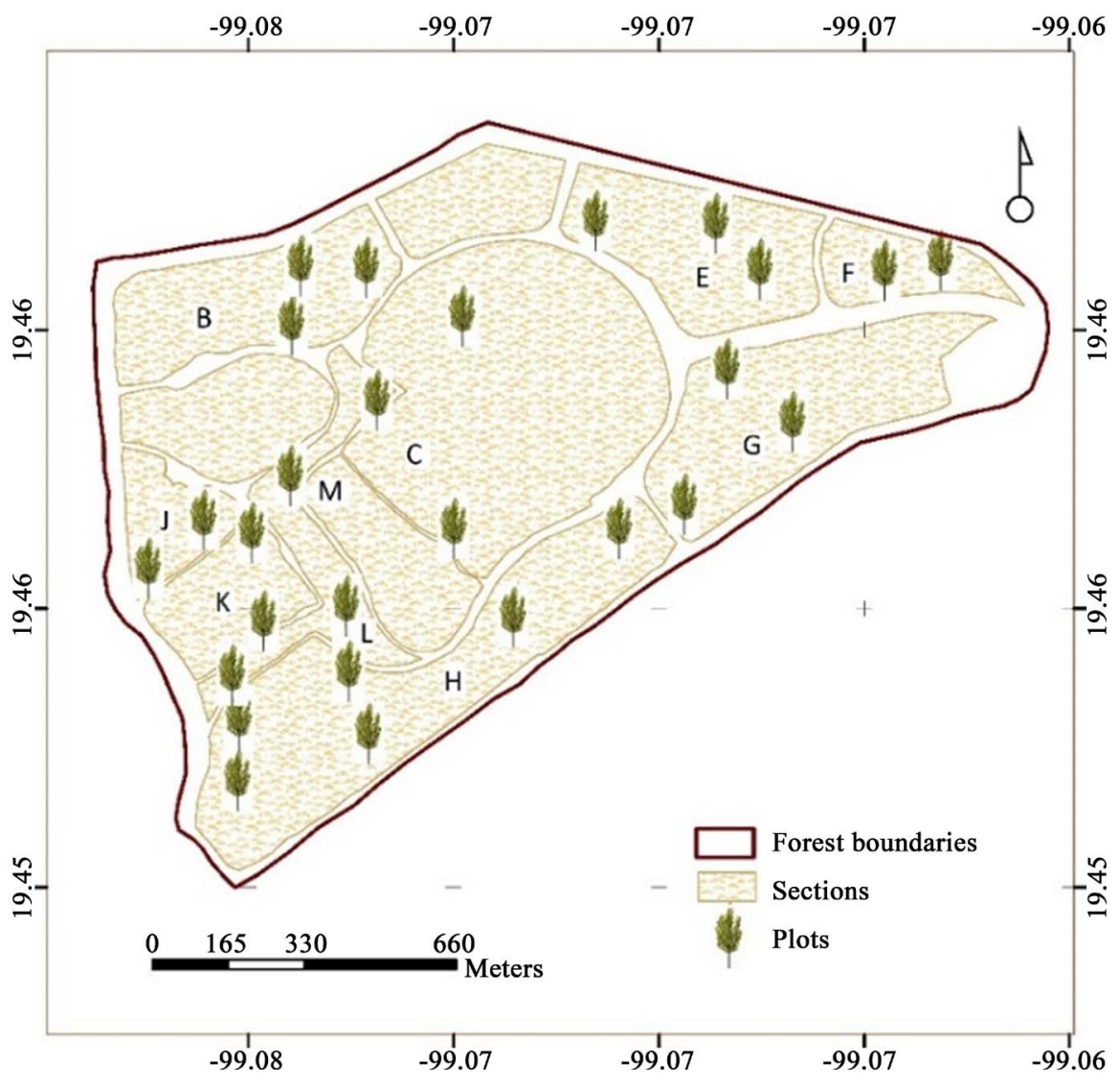

Figure 1. Map of San Juan de Aragon Park, Mexico City (Saavedra-Romero et al., 2019a).

crew integrated by three people (two Biologists and one Forest Engineer) was trained to identify the main symptoms and to calibrate some of the more subjective measures, like damage severity. In this survey, up to two damaging agents per live tree were recorded (Type 1 and Type 2) as well as the location and severity of each damage. Type 1 represents the causal agent with the greatest damage caused to the tree (highest severity), and Type 2 represents the causal agent with lesser damage (lowest severity). Each tree was visually inspected at $360^{\circ}$ to obtain a complete view with an ascending order of evaluation: root and root collar $>$ stem $>$ branches and foliage. Only damage considered serious enough to increase the probability of death (e.g. by infection of lethal pathogens through open wounds) (Coulston et al., 2005) or premature fall (Saavedra-Romero et al., 2019b) of the trees were considered, as well as those which could affect their growth and reproductive potential (e.g. pathogens that cause foliar diseases and consequently high defoliation) (Coulston et al., 2005). Because of this, a minimum threshold of $20 \%$ was considered for a damage to be recorded. Damage severity observed in the field was recorded in $5 \%$ class intervals. On the stem, the percentage of the circumference damaged was evaluated, whereas in the canopy the percentage of branches or foliage affected was estimated. To record data, a field guide was used for each damaging agent, and a recording key and codes for the nature of the agent. This information was enriched with observations made 
during field trips and finally grouped into six general categories and 34 damaging agents (Saavedra-Romero et al., 2015).

\subsubsection{Location of Damage}

Damage location affects differently the overall health of the tree (Coulston et al., 2005), for this reason, damages identified on lower organs (root, root collar and stem) were considered more threatening to structural integrity and were weighted as follows: 1) Foliage (leaves or needles); 2) Branches; 3) Stem, and 4) Root and root collar area.

\subsubsection{Nature of the Damaging Agent}

The effect of the damaging agent on individual trees was rated according to the danger it represented to its health and integrity, that is, lower values mean less dangerous (e.g. the birds), and higher values mean more dangerous (e.g. the Seiridium canker). Values from 1 to 4 were employed, where 4 represents the highest danger (Table 1).

\subsubsection{Damage Severity}

Regarding this component and considering the established threshold (20\%), seven categories were set up according to the percentage of stem circumference or affected canopy: code $1(\geq 20 \%-29 \%)$, code $2(30 \%-39 \%)$, code $3(40 \%-$ $49 \%)$, code $4(50 \%-59 \%)$... code $7(>80 \%)$.

\subsection{Damage Severity Index (DSI) and Health Categories}

According to Conkling et al. (2005), a damage severity index (DSI) score was determined for each damaged tree. The DSI score was determined based on three variables collected a priori in the field: 1) the location of the damage on the tree, 2) the nature of the damaging agent, and 3) the severity of the damage. A DSI

Table 1. Codes employed for the nature of the damaging agent for San Juan de Aragon Park, Mexico City.

\begin{tabular}{|c|c|c|c|}
\hline \multicolumn{4}{|c|}{ Codes/Damaging agents } \\
\hline 1 & 2 & 3 & 4 \\
\hline Unknown agent & Cytospora canker & Struthanthus sp. & Pitch canker \\
\hline Phyllosticta leaf spot (Phyllosticta sp.) & Tubercularia canker & Cladocolea sp. & Seiridium canker \\
\hline Ash plant bug (Tropidosteptes sp.) & Red gum lerp psyllid (Glycaspis sp.) & Stem insects & Wood decay \\
\hline Pepper tree psyllid (Calophya sp.) & Bleeding & Galls & Wind \\
\hline Defoliating insects & Sooty molds & Cavities & Girdling \\
\hline Birds & Water excess & Cracks & \\
\hline Rodents & Mechanical wounds & Fire & \\
\hline Air pollution & Topping & & \\
\hline Inadequate cultural practices & & & \\
\hline
\end{tabular}


for tree species and sections were calculated. Finally, based on this, health categories were established. The following Equations (1) and (2) were applied:

$$
\begin{gathered}
\text { DSI by tree }=\left(L_{1}+D_{1}+S_{1}\right)+\left(L_{2}+D_{2}+S_{2}\right) \\
\text { DSI by section or species }=\frac{1}{n}\left[\left(L_{1}+D_{1}+S_{1}\right)+\left(L_{2}+D_{2}+S_{2}\right)\right]
\end{gathered}
$$

where:

$L_{1}$ y $L_{2}=$ Location of damage (1 and 2);

$D_{1}$ y $D_{2}=$ Type of damaging agent ( 1 and 2);

$S_{1}$ y $S_{2}=$ Severity of damage (1 and 2);

$n=$ number of trees per section or species.

\subsection{Data Analysis}

The DSI data obtained were compared among tree species and sections with nonparametric analysis using the Kruskall-Wallis test and the Wilcoxon rank sum test using the SAS software v. 9.4.

\section{Results}

The Damage Severity Index (DSI) was obtained for 753 live trees in San Juan de Aragon Park (SJAP). Ten botanical families were identified, with the most representative being Casuarinaceae (23.60\%), Proteaceae (17.50\%) and Cupressaceae $(17.24 \%)$, in addition to 12 species (10 broadleaves and two conifers). The frequency of each one was as follows: Australian pine (Casuarina equisetifolia L.) (23.60\%), silk oak (Grevillea robusta A. Cunn. Ex. R. Br.) (17.24\%), Mexican white cedar (Hesperocyparis lusitanica (Mill.) Bartel (13.66\%), red gum (Eucalyptus camaldulensis Dhnh.) (12.06\%), California pepper (Schinus molle L.) (9.68\%), tropical ash (Fraxinus uhdei (Wenz.) Lingelsh. (8.09\%), everblooming acacia (Acacia retinodes Schltdl. (7.55\%), Mediterranean cypress (Cupressus sempervirens L.) (3.84\%), tamarisk (Tamarix gallica L.) (3.05\%), glossy privet (Ligustrum lucidum Aiton) (0.79\%), Chinese elm (Ulmus parvifolia Jacq.) and boxelder (Acer negundo L.) (0.13\%) (Saavedra-Romero et al., 2019a).

\subsection{Incidence of Tree Damage}

Of the total number of trees, $48.50 \%$ showed no significant damage, or they were below the established $\leq 20 \%$ threshold. On the other hand, of the 388 remaining trees, $29.60 \%$ showed one type of damage (223) (type 1) and $21.90 \%$ showed two (165) (type 2).

\subsection{Damaging Agents and Affected Organs}

At least 27 damaging agents were identified. Figure 2 shows only 18 of them which affected more than 15 trees $(n \geq 15)$. The affected organs were the stem with $61 \%$, branches with $32 \%$, foliage with $4 \%$ and root collar area with only $3 \%$ (Figure 3). 


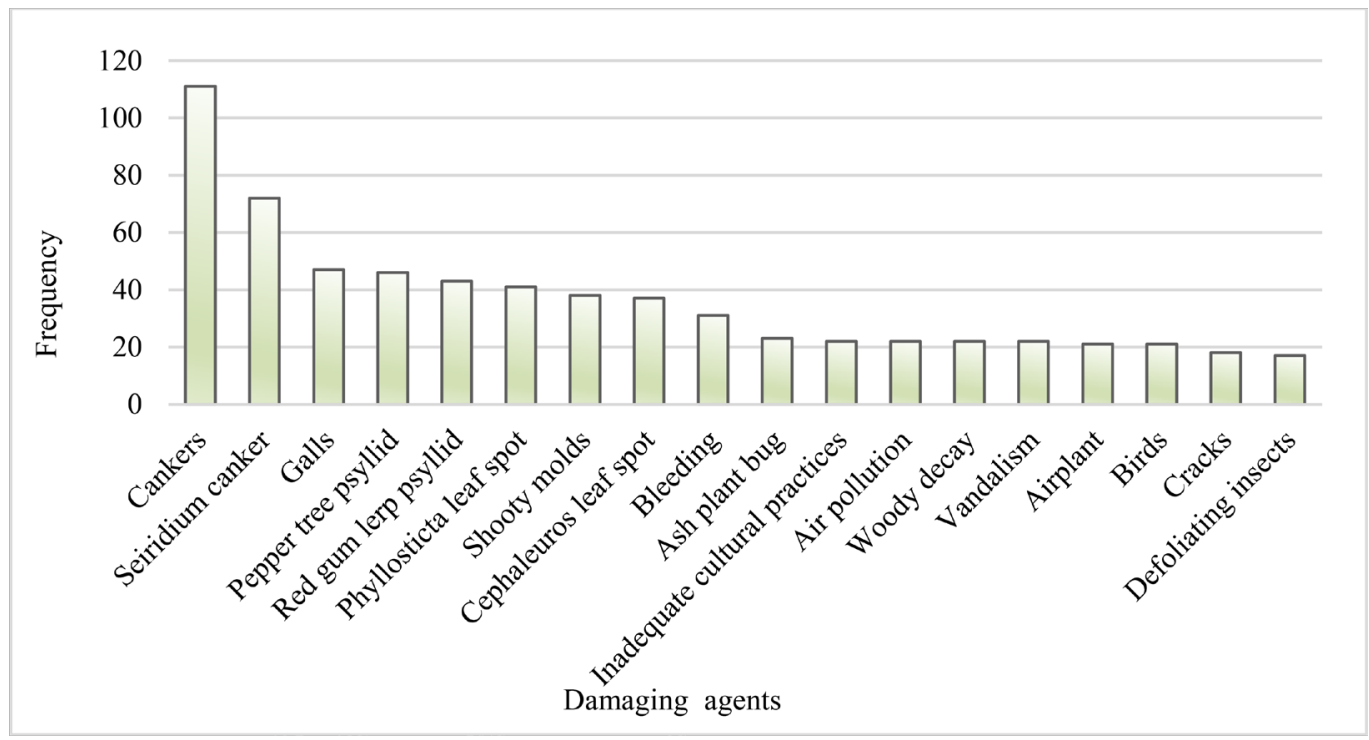

Figure 2. Frequency of damaging agents identified in San Juan de Aragon Park, under the criterion $\mathrm{n} \geq$ 15 affected trees.

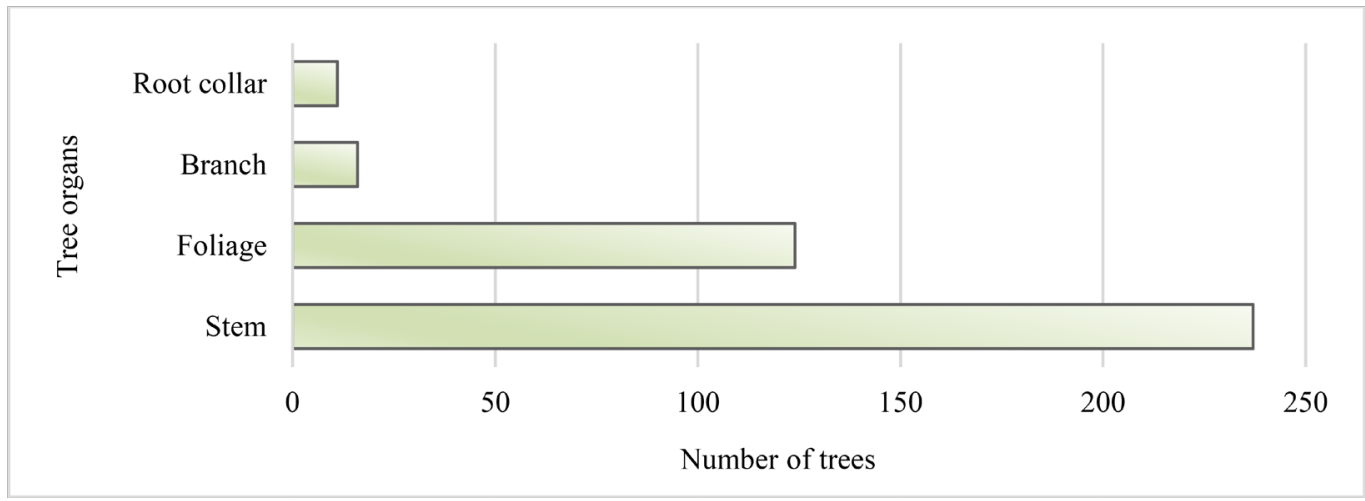

Figure 3. Number of damaged trees depending of the affected organ.

\subsection{Damaging by Tree Species and by Sections}

Tree species with the most damaging agents' number were: Australian pine, red gum and California pepper. Regarding tree species with the highest number of damaged trees were Mexican cedar, Mediterranean cedar, California pepper, red gum and silk oak (Table 2).

Stem damage caused by Seiridium canker was the most important damaging agent with $53 \%$ incidence on Mexican white cedar and $62 \%$ on Mediterranean cypress. Three species showed serious foliar damage: Everblooming acacia by Cephaleuros leaf spot (Cephaleuros sp.), with and incidence of $64.9 \%$; red gum tree by sooty molds and the red gum lerp psyllid, with incidences of $45 \%$ and $57 \%$, respectively, and finally, California pepper by pepper tree psyllid. Regarding the sections of the SJA Park included in this study, cankers were found to be the most frequent damage; for example, $28 \%$ of the trees in section $\mathrm{E}$ were affected, followed by Sections H and B with $11.86 \%$ and $10.97 \%$, respectively. The rest of sections showed lower values. 


\subsection{Damage Severity Index and Health Categories by Sections and Species}

According to the gross DSI scores obtained, the minimum was 3 and the maximum 17, with an average population score of 7.90. Of the total number of damaged trees, $71.90 \%$ presented damage severity indexes between 3 and 9 . Damage Severity Indexes showed significant differences between sections $(p=0.0001)$ and tree species $(p<0.0001)$ of the SJA park (Table 3$)$. The DSI for sections E, $\mathrm{H}$ and $\mathrm{J}$ were significantly greater than sections $\mathrm{G}$ and $\mathrm{K}$, while sections $\mathrm{B}, \mathrm{C}, \mathrm{F}$,

Table 2. Frequency of damaging agents by tree species in San Juan de Aragon Park, Mexico City (included those affecting more than 15 trees).

\begin{tabular}{|c|c|c|c|c|c|c|c|c|c|c|c|c|c|c|c|c|c|c|c|c|}
\hline Species & 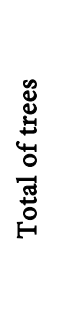 & $\begin{array}{l}\stackrel{\tilde{z}}{\widetilde{J}} \\
\text { Uू }\end{array}$ & 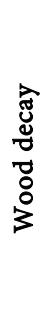 & 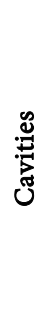 & 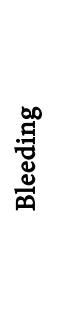 & 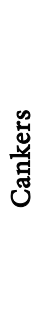 & 㞼 & 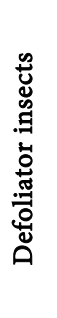 & 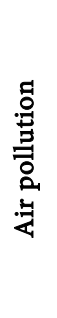 & 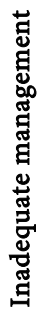 & 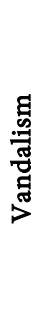 & 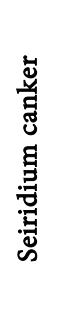 & 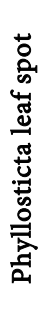 & 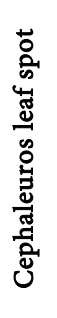 & 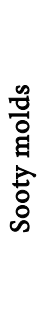 & 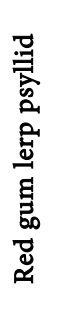 & 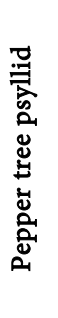 & 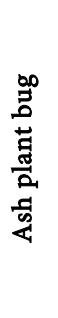 & 蒙 & 苟 \\
\hline Australian Pine & 178 & 11 & 3 & & 13 & 18 & 1 & & 1 & 4 & 4 & & & & & & & & 17 & 19 \\
\hline Silk oak & 130 & 1 & & & 22 & 25 & & & 20 & 5 & 5 & & & & & & & & & \\
\hline Mexican white cedar & 103 & 2 & & & & 15 & & & & 2 & 8 & 52 & & & & & & & & \\
\hline Red gum & 91 & & & & & 4 & & 17 & & 2 & 2 & & 40 & & 37 & 43 & & & & \\
\hline Californian pepper & 73 & 1 & 15 & 9 & & 11 & 27 & & & & & & & & & & 46 & & 4 & 1 \\
\hline Tropical ash & 61 & 1 & & & & 12 & & & & 3 & 3 & & & & & & & 23 & & \\
\hline Everblooming acacia & 57 & 2 & & & & 12 & & & & & & & & 37 & 1 & & & & & \\
\hline Mediterranean cypress & 29 & & & & & 3 & & & & 1 & & 29 & & & & & & & & 1 \\
\hline Tamarisk & 23 & & 4 & 1 & & & 19 & & & & & & & & & & & & & \\
\hline
\end{tabular}

Table 3. Mean values of Damage Severity Index (DSI) by sections and tree species of San Juan de Aragon Park, Mexico City.

\begin{tabular}{cccc}
\hline Sections & DSI & Tree species & DSI \\
\hline G & $6.20^{\mathrm{a \dagger}}$ & Tropical ash & $5.86^{\mathrm{a}}$ \\
K & $6.71^{\mathrm{ab}}$ & Red gum & $6.43^{\mathrm{a}}$ \\
$\mathrm{L}$ & $7.34^{\mathrm{abc}}$ & Everblooming acacia & $6.54^{\mathrm{ab}}$ \\
$\mathrm{B}$ & $7.56^{\mathrm{bc}}$ & Silk oak & $7.89^{\mathrm{bc}}$ \\
$\mathrm{F}$ & $7.71^{\mathrm{bc}}$ & Mediterranean cypress & $7.85^{\mathrm{bcd}}$ \\
$\mathrm{C}$ & $7.86^{\mathrm{abc}}$ & Australian pine & $8.55^{\mathrm{cd}}$ \\
$\mathrm{E}$ & $8.52^{\mathrm{c}}$ & Mexican white cedar & $8.73^{\mathrm{cd}}$ \\
$\mathrm{J}$ & $8.68^{\mathrm{c}}$ & Tamarisk & $9.17^{\mathrm{cd}}$ \\
$\mathrm{H}$ & $8.82^{\mathrm{c}}$ & California pepper & $9.84^{\mathrm{d}}$ \\
\hline
\end{tabular}

${ }^{\dagger}$ Different letters within columns indicate differences between sections $(\mathrm{p}=0.0001)$ and tree species $(\mathrm{p}<$ 0.0001) using Wilcoxon rank sum test. 
$\mathrm{K}$, and $\mathrm{L}$ were significantly equal to each other and had an average DSI ranging from 6.71 to 7.86. In the case of species, California pepper, tamarisk, Australian pine, and Mexican white cedar presented the highest DSI (8.55 to 9.84) and were significantly different from tropical ash, red gum and everblooming acacia, which presented the lowest values (DSI $=5.86$ to 6.54 ). The remaining species, Silk oak, Australian pine, and Mediterranean cypress, had very similar values ranging from 7.85 to 8.73. Mexican cedar and California pepper, the most frequent species in sections $\mathrm{J}$ and $\mathrm{H}$.

In this study, the general health condition was grouped into three categories based on average DSI values (Table 4). Sections J and H, and Mexican white cedar, tamarisk, and California pepper species showed the poorest health condition. Meanwhile tropical ash, everblooming acacia and red gum showed a good health condition.

\section{Discussion}

Most trees are planted in their definitive place within the urban setting and they have been exposed to the onslaught of different damaging agents throughout its different growth stages; therefore, identifying damaging agents is a priority in an effort to maintain and prolong what is collectively now known as ecosystem services (Johnston \& Hirons, 2014; Morgenroth et al., 2016; Thom \& Seidl, 2016; Bravo-Bello et al., 2020).

\subsection{Incidence of Tree Damage}

Currently, most studies worldwide on damaging agents specify the affected surface and spatial distribution of general or specific agents (USDA, 2009). Unfortunately, few assess the amount of individual damage, their diversity, incidence, and severity. In 2012, the ICP Forest carried out an evaluation of damage on 64 thousand trees in 25 European countries, and their results showed that $72 \%$ (46,500 trees) presented some kind of damage. However, due to one individual being able to host more than one damaging agent, the total number of cases recorded at the end was 62 thousand (Michel et al., 2014). In a similar study, damaging

Table 4. Health categories for sections and tree species of San Juan de Aragon Park, Mexico City, according to the average value of the Damage Severity Index.

\begin{tabular}{|c|c|c|c|c|}
\hline $\begin{array}{l}\text { Health } \\
\text { condition }\end{array}$ & DSI & Description of damage and thresholds & Sections & Species \\
\hline Good & $\leq 6.6$ & $\begin{array}{l}\text { Damage mainly in foliage, and minor in } \\
\text { branches or trunk, and severity percent } \\
\qquad(20 \text { and } 29) \text {. }\end{array}$ & G & $\begin{array}{l}\text { Tropical ash } \\
\text { Everblooming acacia } \\
\text { Red gum }\end{array}$ \\
\hline Moderate & $>6.6$ to 8.6 & $\begin{array}{l}\text { Damage mainly in branches and trunk, } \\
\text { and severity percent of } 30 \text { to } 49 \text {. }\end{array}$ & $\begin{array}{l}\mathrm{B}, \mathrm{C}, \mathrm{E} \\
\mathrm{F}, \mathrm{K}, \mathrm{L}\end{array}$ & $\begin{array}{l}\text { Silk oak } \\
\text { Mediterranean cypress } \\
\text { Australian pine }\end{array}$ \\
\hline Poor & $>8.6$ & $\begin{array}{l}\text { Damage mainly in trunk and root collar, } \\
\text { and severity percent }>50 \% \text {. }\end{array}$ & $\mathrm{J}, \mathrm{H}$ & $\begin{array}{l}\text { Mexican white cedar } \\
\text { Tamarisk } \\
\text { California pepper }\end{array}$ \\
\hline
\end{tabular}


agents were recorded on 251 trees at three sites in Tanzania, two nature reserves (Kimboza and the teachers' college) and a mountainous area in Usambara. The percentage of trees with damage were $32 \%, 53 \%$ and $23 \%$, respectively, while the percentage of trees with two types were 3\%, 29\% and 9\%, respectively (Madoffe et al., 2006). In our study, $51.50 \%$ of the trees showed damage. Leastways $29.60 \%$ displayed one type of damage, and $21.90 \%$ showed two. These results were similar to the ones previously mentioned.

\subsection{Damaging Agents and Affected Organs}

Regarding damaging agents, cankers, galls, the pepper tree psyllid (Calophya rubra (Tuthill)) and the red gum lerp psyllid (Glycaspis brimblecombei Moore) were the most frequent. With lower incidence, the parasitic plant, Struthanthus sp., and the epiphyte, Tillandsia sp. were identified. The latter, despite being epiphytic, competes with its host for space and light, and some studies report that it affects the reproductive potential of its host (Castellanos-Vargas et al., 2009). Concerning mistletoe, trees presented low levels of infection; unfortunately, these two damaging agents could, in the short term, become a major problem due to the existence of trees with high levels of severity in areas adjacent to the SJA Park. Similar studies conducted by Applegate and Steinman (2005), report six damaging agents for the species Virginia pine (Pinus virginiana Mill.), loblolly pine (Pinus taeda L.) and the oaks (Quercus spp.) on army training fields at Fort A.P. Hill in Virginia, U.S.A. being the most frequent are those that cause trunk rot and different types of wounds. Whit regard to the present study, the stem was also one of the most damaged organs, followed by branch damage (Figure 3). On the other hand, other studies pointed out 12 damaging agents, including cankers, rots, wounds and broken branches in the high part of the canopy (Rogers, 2002). Meanwhile, decay and vines were considered the most serious damaging agents in Kimboza forest reserve (Madoffe et al., 2006). Another studies on damage assessment carried out in Trentino, Italy, reports the presence of 13 specific agents; the most frequent were anthracnose of the oaks (Gnomonia quercina Kleb.) and common spruce bell (Epinotia tedella (Clerk)), four abiotic agents (snow, lightning, drought, and frost) and two types of mechanical damage (Maresi \& Salvadori, 2004).

Meanwhile, in United Kindom, information about the main tree damage agent was gathered through the use of an extensive questionnaire answered by administrators and people responsible for green areas in 17 European countries. Some of the most noteworthy results include insects that produce scales and aphids, diseases such as anthracnosis, powdery mildew and Dutch elm disease, environmental pollution and damage by salts; but without a doubt, the most significant result was the vandalism inflicted on $30 \%$ of the trees (Pauleit et al., 2002). In comparison with the precedent studies, the number of damaging agents identified in the SJA park was greater, since the identification in some cases was at a specific level. Even though the identification of a greater number of damaging 
agents per tree implies a greater effort, but it has the advantage of providing a most complete picture of all damages that can be diminishing tree health and which are the most frequently damaged organs (Figure 3). Finally, this information will allow establishing prompt management actions.

\subsection{Damaging by Tree Species and by Sections}

Canker Seiridium was the most aggressive damaging agent on Mexican white cedar and Mediterranean Cypress. This kind of damage is known to affect trees growing under stress conditions (García-Díaz \& Cibrián-Tovar, 2007). In the infected trees, the size of the wounds sometimes surpasses $50 \%$ of the circumference of the trunk. Fungi that are active on the surface of the wound can also deteriorate the structures of lower woody tissues, weakening the tree. A weak and structurally useless tree can die and become a hazard to people nearby (Purcell, 2014; Saavedra-Romero et al., 2019b). This type of disease is known to have a long-term effect and is favored by poor soil conditions, inadequate cultural practices (wounds caused by mowing) and a high plantation density, which favors the spreading of the pathogen. An additional factor that may be contributing to the increase in Seiridium canker incidence in the SJA urban forest is the lack of preventive measures, since there are no programs for cutting down and tree removal of diseased or dead trees, leading to the year-round presence of inoculum.

Australian pine and silk oak were the species with the highest bleeding incidence. In the short term, in the last species, it could be increased by the excessive moisture, exacerbated by the organic residues incorporation at the root collar area and the inadequate planting. This kind of information will help to implement better management strategies for this species, since it could be a bacterial disease. In Californian pepper the presence of galls reached an incidence of $42 \%$ and the causal agent identified in previous studies is Agrobacterium tumefaciens Smith El Townsed (Fucikovsky, 2007).

Regarding stem damage, inappropriate cultural practices, for example, damage by the mowers, poor irrigation practices (too much or too little water), inadequate planting depth (too shallow or too deep), among others (Costello et al., 2003), could be contributing to the damage recorded in SJA park. Finally, from the perspective of management, it may be possible in the short term to prioritize the allocation of resources to improve the condition of these species and sections of the park.

These results show that the most frequent species, and therefore those with the highest predisposition to this type of cortex damage, exert a considerable effect on the percentages found in each section. In general terms, a large proportion of the damage identified in the SJA urban park also includes other factors, like poorly implemented management activities and increasing stress caused by the thousands of visitors who visit this park annually. In this sense, in some sections of the site, it was observed that sports and recreational activities favor tree 
damage (Saavedra-Romero et al., 2019b). Two important factors that could be increasing the incidence of damage is the aging of those trees that are now around 50 years old and site conditions since trees were planted in saline soils (SMA, 2012).

\subsection{Damage Severity Index and Health Categories}

The Damage Severity Index was implemented as a tool to evaluate the degree of damage caused by multiple damaging agents in urban trees (Table 1). This index integrates all the scores of the variables assessed in the field, in a single additive value (Andrews et al., 2004, Conkling et al., 2005). The combination of scores of each variable (Equations (1) and (2)) express in a numerical way the severity of the damage in situ. The final DSI score reflects health condition of the tree and for practical purposes, that one, or more damaging agents are present, so, the higher the value (ISD average $>8.6$ ), the greater the damage (Table 4). High scores were associated with damage circumscribed to the stem and root collar area, in combination with severities greater than $50 \%$. While low scores $(<6.6)$ defined the trees with foliar damage mainly, and to a lesser extent in branches and trunk, and damage severity less than $29 \%$. Regarding species and sections of the forest, the following was found (Table 3). In the first group, that is, with high IDS scores, Mexican white cedar, tamarisk and California pepper were found, as well as sections $\mathrm{J}$ and $\mathrm{H}$, with low scores, tropical ash, everblooming acacia, red gum, and section $\mathrm{G}$.

Finally, the general health condition for species and sections of the park, was grouped into three categories (Table 4). The first, classified as good health, was for ash tree, red gum and everblooming acacia. In opposition, the poor health was for Mexican white cedar, tamarisk and California pepper.

The generation of indexes to explain biological topics is diverse worldwide. These include, for example, those to determine quality of agricultural and forest soils, trends in their health, promote and improve management practices and to make them more sustainable (Andrews et al., 2003, 2004; Amacher et al., 2007). More recently, the Soil Conditioning Index (SCI), like a predictive tool to assess trends in soil organic carbon (Karlen et al., 2008). On the other hand, in commercial forest plantations, they have been created to determine the extent of damage and estimate future losses (Stone et al., 2003a), among others. These indexes, however, have limited application in urban landscapes where geographic conditions, diversity of tree species, and site conditions differ substantially. Among the indices that have been generated for urban green areas, the Rapid Urban Site Index (RUSI) stands out, which accurately relates the health and growth of the urban tree (Scharenbroch et al., 2017). In the future, these indexes may become attractive and fruitful as monitoring tools. With this background, the DSIs obtained in the present study allowed in a simple way, determine the current tree health status, and in the long term help in the selection of tree species, and improve management activities, in order to extend the lifespan of trees 
and to preserve their benefits.

\section{Conclusion}

The tree damage indicator was applied to assess urban tree health at the SJA Park. Using this protocol, 27 damaging agents were identified. In $29.60 \%$ of the trees, one type of damage was recorded, and $21.90 \%$ presented two. Trunk and branches were the most affected organs. Cankers, galls, the pepper tree psyllid and the red gum lerp psyllid were the most frequent damaging agents. Australian pine, red gum, Mediterranean cypress, Mexican white cedar, and California pepper were the most affected species.

The DSI ranged from 3 to 17 and the average was 7.90. Sections $J$ and $H$ and the species California pepper, Australian pine, and Mexican white cedar presented the highest DSI. Based on the health categories established in this study, the tree population had a moderate health condition, while the aforementioned sections and tree species showed the poorest. Finally, tree damage identification and DSI scores will help to identify tree species and urban green areas in danger of having their potential growth decreased or mortality rates increased. Counting with this information, will help plan activities, allocate resources, and train the staff in charge of carrying out management practices in the best possible way.

\section{Conflicts of Interest}

The authors declare no conflicts of interest regarding the publication of this paper.

\section{References}

Alexander, S. A., \& Palmer, C. J. (1999). Forest Health Monitoring in the US: First Four Years. Environmental Monitoring Assessment, 55, 267-277. https://doi.org/10.1023/A:1005905310299 https://link.springer.com/content/pdf/10.1023/A:1005905310299.pdf

Alvarado-Rosales, D., \& Saavedra-Romero, L. L. (2005). El Género Cladocolea (Loranthaceae) en México: Muérdago Verdadero o Injerto. Revista Chapingo, Serie Ciencias Forestales y del Ambiente, 11, 5-9. http://redalyc.org/articulo.oa?id=62911101

Alvarado-Rosales, D., Saavedra-Romero, L. L., Fenn, M., Hernández-Tejeda, T., \& Cibrián-Tovar, D. (2007). Abiotic Factors That Causes Stress and Death. In D. Cibrián-Tovar, D. Alvarado-Rosales, \& S. E. García-Díaz (Eds.), Forest Diseases in Mexico (pp. 11-41). Chapingo: UACH, CONAFOR-SEMARNAT, USDA-Forest Service, COFAN-FAO.

Amacher, M. C., O’Neil, K. P., \& Perry, C. H. (2007). Soil Vital Signs: A New Soil Quality Index (SQI) for Assessing Forest Soil Health. RMRS-RP-65WWW, Fort Collins, CO: Department of Agriculture, Forest Service, Rocky Mountain Research Station. http://citeseerx.ist.psu.edu/viewdoc/download?doi=10.1.1.462.8948\&rep=rep1\&type $=$ p df

Andrews, S. S., Douglas, L. K., \& Cambardella, C. A. (2004). The Soil Management Assessment Framework: A Quantitative Soil Quality Evaluation Method. Soil Science Society of America Journal, 68, 1945-1962. https://doi.org/10.2136/sssaj2004.1945 
Andrews, S. S., Flora, C. B., Mitchell, J. P., \& Karle, D. L. (2003). Grower's Perceptions and Acceptance of Soil Quality Indices. Geoderma, 114, 187-213. https://doi.org/10.1016/S0016-7061(03)00041-7

Applegate, J. R., \& Steinman, J. (2005). A Comparison of Tree Health among Forest Types and Conditions at Fort A.P. Hill, Virginia. Southern Journal of Applied Forestry 29, 143-147. https://www.researchgate.net/publication/233524828 https://doi.org/10.1093/sjaf/29.3.143

Bravo-Bello, J. C., Martínez-Trinidad, T., Romero-Sánchez, M. E., Valdez-Lazalde, J. R., \& Benavidez-Meza, H. (2020). The Analytic Hierarchy Process for Selection of Suitable Trees for Mexico City. iForest, 13, 541-547. https://doi.org/10.3832/ifor3481-013

Castellanos-Vargas, I., Cano-Santana, Z., \& Hernández-López, B. (2009). Efecto de Tillandsia recurvata L. (Bromeliaceae) Sobre el Éxito Reproductivo de Fouquieria splendens Engelm. (Fouquieriaceae). Ciencia Forestal en México, 34, 197-207. http://cienciasforestales.inifap.gob.mx/editorial/index.php/forestales/article/view/690

Conkling, B. L., Coulston, J. W., \& Ambrose, M. J. (2005). Forest Health Monitoring: 2001 National Technical Report. Gen. Tech. Rep. SRS-84, Ashville, NC: U.S. Department of Agriculture, Forest Service, Southern Research Station.

https://www.srs.fs.usda.gov/pubs/20552

https://doi.org/10.2737/SRS-GTR-81

Costello, L. R., Perry, E. J., Matheny, N. P., Henry, J. M., \& Geisel, P. M. (2003). Abiotic Disorders of Landscape Plants, a Diagnostic Guide. Agriculture and Natural Resources, University of California, Publication 3420, Canada.

Coulston, J. W., Ambrose, M. J., Riitters, K. H., \& Conkling, B. L. (2005). Forest Health Monitoring: 2002 National Technical Report. Gen. Tech. Rep. SRS-84, Ashville, NC: U.S. Department of Agriculture, Forest Service, Southern Research Station. https://www.srs.fs.usda.gov/pubs/20552 https://doi.org/10.2737/SRS-GTR-84

Ferretti, M. (1997). Forest Health Assessment and Monitoring-Issues for Consideration. Environmental Monitoring Assessment, 48, 45-72. https://www.icp-forests.org/pdf/FerrettiEMAS1997.pdf

Fucikovsky, Z. L. (2007). Crown Gall, Agrobacterium tumefaciens (Smith El Townsed). (Tenericutes, Rhizobiaceae). In D. Cibrián-Tovar, D. Alvarado-Rosales, \& E. GarcíaDíaz (Eds.), Forest Diseases in Mexico (pp. 314-317). Chapingo: UACH, CONAFORSEMARNAT, USDA-Forest Service, COFAN-FAO.

García-Díaz, S. E., \& Cibrián-Tovar, D. (2007). Canker of Cypress. Seiridium unicorne (Cooke \& Ellis) B. Sutton. (Melanconiales, Melanconiaceae). In D. Cibrián-Tovar, D. Alvarado-Rosales, \& S. E. García-Díaz (Eds.), Forest Diseases in Mexico (pp. 180-181). Texcoco: Chapingo Autonomous University.

Johnston, M., \& Hirons, A. (2014). Urban Trees. In G. R. Dixon, \& D. E. Aldous (Eds.), Horticulture: Plants for People and Places (Vol. 2, Chapter 20, pp. 693-711). Berlin: Springer. https://doi.org/10.1007/978-94-017-8581-5 5 https://www.researchgate.net/publication/269631711 Urban Trees Chapter 20

Karlen, D. L., Andrews, S. S., Wienhold, B. J., \& Zobeck, T. M. (2008). Soil Quality Assessment: Past, Present and Future. Journal of Integrative Biosciences, 6, 3-14. https://digitalcommons.unl.edu/usdaarsfacpub/1203

Klieber, T., Krzyżaniak, M., Świerk, D., Haenel, A., \& Gałecka, S. (2019). How Does the Content of Nutrients in Soil Affect the Health Status of Trees in City Parks? PLOS ONE, 14, e0221514. https://doi.org/10.1371/journal.pone.0221514

Konijnendijk, C. C., Nilsson, K., Randrup, T. B., \& Schipperijn, J. (2005). Urban Forest 
and Trees. Berlin: Springer. https://doi.org/10.1007/3-540-27684-X

Lorenz, M. (2013). FutMon Scientific Report. Hamburg: Thünen Institute for World Forestry. http://www.futmon.org/scientific-report-final-version.pdf

Madoffe, S., Hertel, G. D., Rodgers, P., O’Connell, B. O., \& Raymond, K. (2006). Monitoring the Health of Selected Eastern Arc Forests in Tanzania. African Journal of Ecology, 44, 171-177. https://doi.org/10.1111/j.1365-2028.2006.00606.x

Maresi, G., \& Salvadori, C. (2004). Crown Condition and Damage in Two Forest Ecosystems in Trentino (Italy). Studi Trentini di Scienze Naturali Acta Biologica, 81, 253-260. https://www2.muse.it/pubblicazioni/5/actaB81s1/14.pdf

McPherson, E. G. (1993). Monitoring Urban Forest Health. Environmental Monitoring Assessment, 26, 165-174. https://link.springer.com/article/10.1007/BF00547494 https://doi.org/10.1007/BF00547494

Michel, A., Seidling, W., Lorenz, M., \& Becher, G. (2014). Forest Condition in Europe 2013 Technical Report of the ICP Forest. Report under the UNECE Convention on Long-Range Transboundary Air Pollution (CLRTAP). Thünen Working. http://hdl.handle.net/10419/96108

Morgenroth, J., Ostberg, J., Van Den Bosch, C. K., Nielsen, A. B., Hauer, R., Sjöman, H., \& Jansson, M. (2016). Urban Tree Diversity-Taking Stock and Looking Ahead. Urban Forestry and Urban Greening, 15, 1-5. https://doi.org/10.1016/j.ufug.2015.11.003

Nowak, D. J., Kuroda, M., \& Crane, D. E. (2004). Tree Mortality Rates and Tree Population Projections in Baltimore, Maryland, USA. Urban Forestry and Urban Greening, 2, 139-147. https://doi.org/10.1078/1618-8667-00030

Pauleit, S., Jones, N., Garcia-Martín, G., Garcia-Valdecantos, J. L., Rivière, L. M., Vidal-Beaudet, L., Bodson, M., \& Randrup, T. B. (2002). Tree Establishment Practice in Towns and Cities-Results from a European Survey. Urban Forestry and Urban Greening, 1, 83-96. https://doi.org/10.1078/1618-8667-00009

Pretzsch, H., Biver, P., Uhl, E., Dahlhausen, J., Rötzer, T., Caldenty, J., Koike, T., Van Con, T., Chavanne, A., Seifert, T., Toit, B., Farnden, C., \& Pauleit, S. (2015). Crown Size and Growing Space Requirement of Common Tree Species in Urban Centres, Parks, and Forests. Urban Forestry and Urban Greening, 14, 466-479.

https://doi.org/10.1016/j.ufug.2015.04.006

Purcell, L. (2014). Mechanical Damage to Trees: Mowing and Maintenance Equipment. Purdue Extension. FNR-492-W. Purdue University. Forestry and Natural Resources. https://www.extension.purdue.edu/extmedia/FNR/FNR-492-W.pdf

Rogers, P. (2002). Using Forest Health Monitoring to Assess Aspen Forest Cover Change in the Southern Rockies Ecoregion. Forest Ecology and Management, 155, 223-236. https://www.fs.fed.us/rm/pubs other/rmrs 2002 rogers001.pdf https://doi.org/10.1016/S0378-1127(01)00560-6

Roman, L. A., \& Scatena, F. N. (2011). Street Tree Survival Rates: Meta-Analysis of Previous Studies and Application to a Field Survey in Philadelphia, PA, USA. Urban Forestry and Urban Greening, 10, 269-274. https://doi.org/10.1016/j.ufug.2011.05.008

Saavedra-Romero, L. L. (2015). Indicadores de Salud Forestal y su Aplicación en Áreas Verdes Urbanas. PhD Thesis, Colegio de Postgraduados, Estado de México.

Saavedra-Romero, L. L., Alvarado-Rosales, D., Martínez-Trinidad, T., Hernández-de la Rosa, P., \& Villa-Castillo, J. (2019a). Diversity, Tree Structure and Importance Value in an Urban Park in Mexico City. Polibotánica, 47, 25-37.

Saavedra-Romero, L. L., Alvarado-Rosales, D., Martínez-Trinidad, T., \& Hernández-de la Rosa, P. (2019b). Identification of Defects and Risks in Trees of San Juan de Aragon 
Forest, Mexico City. Revista Chapingo Serie Ciencias Forestales y del Ambiente, 25, 3147. https://doi.org/10.5154/r.rchscfa.2018.06.049

Samson, R. (2017). Urban Trees as Environmental Engineers. In D. Pearlmutter, C. Calfapietra, R. Samson, L. O’Brien, S. Krajter, \& G. Sanesi (Eds.), The Urban Forest: Cultivating Green Infrastructure for People and the Environment (pp. 3-5). Berlin: Springer.

Scharenbroch, B. C., Carter, D., Bialecki, M., Fahey, R., Scheberl, L., Catania, M., Roman, L. A., Bassuk, N., Harper, R. W., Werner, L., Siewert, A., Miller, S., Hutyra, L., \& Raciti, S. (2017). A Rapid Urban Site Index for Assessing the Quality of Street Tree Planting Sites. Urban Forestry and Urban Grenning, 27, 279-286.

https://www.fs.fed.us/nrs/pubs/jrnl/2017/nrs 2017 scharenbroch 001.pdf https://doi.org/10.1016/j.ufug.2017.08.017

SMA (2012). Los Bosques Urbanos de Chapultepec y San Juan de Aragón: Sitios Emblemáticos de Importancia Socio-ambiental. Secretaría del Medio Ambiente. México. http://martha.org.mx/una-politica-con-causa/wp-content/uploads/2013/09/06-Bosques -Urbanos.pdf

Stone, C., Matsuki, M., \& Carnegie, A. (2003a). Pest and Disease Assessment in Young Eucalypt Plantations: Field Manual for Using the Crown Damage Index. Canberra: National Forest Inventory Bureau of Rural Science.

https://www.worldcat.org/title/pest-and-disease-assessment-in-young-eucalypt-plantat ions-field-manual-for-using-the-crown-damage-index/oclc/223780083

Stone, C., Wardlaw, T., Floyd, R., Carnegie, A., Wylie, R., \& Little, D. (2003b). Harmonisation of Methods for the Assessment and Reporting of Forest Health in Australia-A Starting Point. Australian Forestry, 66, 233-246.

https://doi.org/10.1080/00049158.2003.10674918

https://www.researchgate.net/publication/238658824

Thom, D., \& Seidl, R. (2016). Natural Disturbance Impacts on Ecosystem Services and Biodiversity in Temperate and Boreal Forest. Biological Reviews, 91, 760-781.

https://doi.org/10.1111/brv.12193

USDA (2009). Major Forest Insect and Disease Conditions in the United States 2007. USDA Forest Service FS-919, Washington DC.

https://www.fs.fed.us/foresthealth/publications/ConditionsReport 2007.pdf

Winn, M. F., Araman, P. A., \& Sang-Mook, L. (2011). Urban Crowns: An Assessment and Monitoring Tool for Urban Trees. Gen. Tech. Rep. SRS-135, Asheville, NC: U.S. Department of Agriculture, Forest Service, Southern Research Station.

https://www.srs.fs.fed.us/pubs/37441

https://doi.org/10.2737/SRS-GTR-135

Wulff, S. (2011). Monitoring Forest Damage. Methods and Development in Sweden. Ph.D. Thesis, Umea: Swedish University of Agricultural Sciences. 